$\begin{array}{lll}\text { KULTURA } & \begin{array}{l}\text { POLSKA A KADEMIA NAUK } \\ \text { KOMITET SOCJOLOGII }\end{array} & \text { ISSN 0023-5172 } \\ \text { i } & \begin{array}{l}\text { INSTYTUT STUDIÓW POLITYCZNYCH } \\ \text { SPOLECZENSTWO }\end{array} & \\ 2018, \text { nr } 1 & \text { GENEALOGIA PODZIAEÓW }\end{array}$

EWA SZCZECIŃSKA-MUSIELAK

Wszechnica Polska

\title{
„WOJENNE” TOŻSAMOŚCI ETNICZNE W SPOŁECZEŃSTWACH POSTKONFLIKTOWYCH - CASUS IRLANDII PÓŁNOCNEJ
}

Rozważania te dotyczą relacji etnicznych we współczesnej Irlandii Północnej, zawierają opis i analizę działań podejmowanych przez różnych aktorów społecznych w celu wygaszenia konfliktu etnicznego oraz budowania płaszczyzn porozumienia i działania wspólnych dla ulsterskich katolików i protestantów. W takim ujęciu sformułowane refleksje odnoszą się do analizowanego przypadku - Ulsteru, aczkolwiek mogą stanowić punkt wyjścia do analiz innych konfliktów etnicznych lub szerszych rozważań o charakterze i istocie tożsamości etnicznej.

Wychodzę z założenia, że warunkiem koniecznym procesu rekoncyliacji i pojednania, budowania społeczeństw postkonfliktowych jest redefiniowanie tożsamości etnicznych. Długotrwałe, wielopokoleniowe konflikty etniczne w szczególny sposób oddziałują na tożsamości grupowe aktorów w nie uwikłanych - pośrednio lub bezpośrednio. Konflikt lub wojna stają się główną osią tożsamości, rezerwuarem symboli, znaczeń i znaków wykorzystywanych przez grupowych liderów i ideologów do budowania tożsamości etnicznej grupy oraz poczucia przynależności i solidarności grupowej.

W przypadku Irlandii Północnej propokojowe zmiany polityczne, kolejne porozumienia między republikanami a lojalistami ${ }^{1}$ oraz wypracowywanie no-

Adres do korespondencji: ewa_szczecinska@wp.pl

${ }^{1}$ Opisując aktorów społecznych i podejmowane przez nich działania, sięgam po terminy występujące zarówno w literaturze przedmiotu, jak i w dyskursie publicznym oraz politycznym. Gdy piszę o ulsterskich protestantach używam określeń: „protestant”, odwołuje się ono nie tylko do wyznania religijnego, ale także (domniemanego, przypisanego) pochodzenia etnicznego (potomek 
wego status quo i zasad nowego podziału władzy trwało od lat osiemdziesiątych XX wieku i zajęło blisko dwadzieścia lat. Krokiem milowym w relacjach protestanci-katolicy stało się Porozumienie Wielkopiątkowe z 1998 roku. Nie zakończyło ono wprawdzie konfliktu definitywnie, ale stworzyło podstawy do proporcjonalnego i bardziej reprezentatywnego udziału we władzach Ulsteru, po raz pierwszy dopuszczając republikańskie Sinn Féin do realnej władzy. Z politycznego punktu widzenia podkreślanie „wojennych” tożsamości — tożsamości etnicznych opartych na konflikcie, niechęci i wrogości - dawało wymierne korzyści w postaci mobilizacji elektoratu i poparcia społeczności dla partii politycznych po obu stronach konfliktu etnicznego. Jednak po wejściu na drogę propokojowych przekształceń systemowych okazało się, że owe tożsamości bardziej przeszkadzają niż pomagają $\mathrm{w}$ procesie pojednania i budowania nowego społeczeństwa. Można zadać pytania: Co się z tymi tożsamościami dzieje i czy widać próby ich przedefiniowania? Jeśli tak, to jakie nowe wartości, postawy czy symbole można zaobserwować i kto je proponuje?

\section{POJĘCIE TOŻSAMOŚCI ETNICZNEJ}

„Tożsamość etniczna” prawdopodobnie jest jedną z kategorii teoretycznych najczęściej używanych przez socjologów i antropologów badających zróżnicowanie etniczne i kulturowe współczesnych (i nie tylko) społeczeństw. Jest traktowana jako niezbywalny atrybut grupy etnicznej i narodu. Jeśli za punkt odniesienia przyjmuje się słynny artykuł Wsievoloda Isajiwa (1974), w którym zawarta jest analiza różnych definicji etniczności, to można powiedzieć, że kategoria tożsamości etnicznej funkcjonuje w obiegu myśli i teorii naukowych od kilkudziesięciu lat.

Oczywiste jest, że wraz ze zmianą kontekstu historycznego i społecznego zmieniały się także sposoby konceptualizowania tożsamości etnicznej od obiektywistycznych zewnętrznych kategoryzacji i wyznaczania granic grup etnicznych po podejście subiektywistyczne uwzględniające autoidentyfikację etniczną jednostek (zob. Bokszański 1999, 2005; Jarymowicz 1992; Melchior 1990; Nowicka 1989; Smith 2009). Ponadto „tożsamość etniczna” funkcjonowała zarówno jako pojęcie teoretyczne, jak i kategoria badawcza, wykorzysty-

szkockich i angielskich osadników, „unionista” w odniesieniu do protestantów popierających polityczną ideę unii Irlandii Północnej z Wielką Brytanią oraz „lojalista” — zwolennik unii państwowej, bardzo mocno zaznaczający swoją „brytyjską tożsamość”, dopuszczający (a nawet inicjujący) stosowanie przemocy wobec „nielojalnych” współobywateli. Analogicznie piszę o „katolikach”, także przypisując wyznaniu religijnemu identyfikację etniczną, dlatego w Ulsterze katolik będzie zapewne Irlandczykiem, a także o „nacjonalistach”, a więc katolikach deklarujących poparcie dla idei przyłączenia Irlandii Północnej do Republiki Irlandii. „Republikanie” zaś akceptują używanie przemocy, aby ów nadrzędny cel uzyskać. Organizacje paramilitarne składają się, odpowiednio, z lojalistów lub po drugiej stronie barykady republikanów (Dixon 2001). 
wana w niezliczonych analizach i opisach grup etnicznych lub małych narodów na całym świecie.

Wydaje się, że mimo ogromnego zróżnicowania sposobów stosowania tej kategorii możemy mówić o kanonicznym zestawie czynników składających się na tożsamość etniczną: wspólnie podzielana tradycja kulturowa, język, religia, przekonanie o wspólnocie pochodzenia i „wspólnocie krwi” oraz symboliczne znaczenie terytorium/ojczyzny.

Jeśli potraktujemy wymienione czynniki jako zmienne, to możemy zauważyć, że:

(1) różne grupy etniczne nie zawsze wykorzystują cały zestaw zmiennych budujących tożsamość etniczną, często sięgają tylko po niektóre elementy;

(2) owe zestawy konstruujące tożsamość etniczną zmieniają się w trakcie historycznego rozwoju i funkcjonowania danej grupy etnicznej, która z czasem może przesuwać akcenty;

(3) ten sam czynnik może być odmiennie konceptualizowany i wykorzystywany przez różne grupy etniczne, na przykład terytorium, ojczyzna mogą mieć znacznie wyłącznie symboliczne, stając się elementem tradycji grupowej (jak u Arumunów; zob. Nowicka 2017), lub być przedmiotem wieloletniej walki i konfliktu między grupami etnicznymi, jak w przypadku Ulsteru;

(4) na poziomie mikro zauważamy ogromną różnorodność postaw jednostek - członków grupy etnicznej — wobec poszczególnych zmiennych tożsamościowych, nie wszyscy w równym stopniu identyfikują się z nimi.

„Wojenną" tożsamość etniczną, odnoszącą się zarówno do grupy etnicznej, jak i do jednostek — członków lub osób uważanych za członków, określiłabym jako typ tożsamości etnicznej konstruowanej i komunikowanej w przestrzeni publicznej na bazie następujących czynników: symbole, wartości oraz postawy afirmacji konfliktu etnicznego, historycznego lub bieżącego. W przypadku konfliktu północnoirlandzkiego takie czynniki to: pamięć społeczna o wydarzeniach i ofiarach konfliktu; obraz grupy własnej i grupy obcej — w tym przypadku „wroga”; wartości wiążące się z ziemią, terytorium definiowanym jako „ojczyzna", konieczność jej obrony oraz walki o jej zachowanie; symbolika związana $z$ wydarzeniami $z$ okresu konfliktu zbrojnego oraz osobami uznawanymi przez grupę etniczną za „ofiary” konfliktu.

\section{KATEGORIA PAMIĘCI SPOŁECZNEJ}

Pamięć społeczna, pamiętanie o wydarzeniach i ofiarach okresu walki zbrojnej między republikańskimi i lojalistycznymi grupami paramilitarnymi, odgrywa kluczową rolę $\mathrm{w}$ budowaniu i afirmowaniu północnoirlandzkich tożsamości etnicznych (zob. Szczecińska-Musielak 2014a; 2015). Przeszłość, historia, korzenie to ważny element kształtowania i legitymizowania tożsamości grupowych, zwłaszcza tożsamości etnicznych/narodowych. Pamięć społeczna składa się na tożsamość etniczną grupy, legitymizuje jej istnienie, integru- 
je, mobilizuje - szczególnego znaczenia nabiera w sytuacji konfliktu etnicznego.

Zarówno historia, jak i pamięć społeczna pełnią ważne funkcje tożsamościowe i integracyjne, mogą służyć budowaniu i zacieśnianiu więzi społecznych wśród tych, którzy uważają się za wspólnotę (zob. Szacka 2006; por. Assmann 2008; Halbwachs 2008; Ricoeur 2006; Saryusz-Wolska 2010). W takim przypadku jest to wspólnota „przeszłych doświadczeń". Niekiedy tak traumatycznych (wojna, utrata bliskich w katastrofie samolotowej), że budują u tych, którzy je przeżywają, silne poczucie odrębności, a nawet obcości względem tych, którzy takich doświadczeń nie mają. „Pamięć o” tworzy zarazem poczucie wspólnoty z innymi uczestnikami. Z kolei odmienne interpretacje historii wydarzeń lub osób - mogą być źródłem konfliktów międzygrupowych (Szpociński 2009).

$\mathrm{Na}$ tożsamościową funkcję historii zwraca uwagę między innymi Marcin Kula (2004) w książce o pożytkach płynących z jej „używania” (w działaniach społecznych oraz ideologii). Jednym $z$ takich pożytków są „korzenie”, a więc konstruowane wyobrażenia o przodkach. Inny przykład użytkowania historii to „znaki tożsamości” — zdaniem Marcina Kuli wiele grup identyfikuje się dzięki odwołaniu do wybranych „materialnych korelatów tożsamości” (termin Stanisława Ossowskiego): zabytków, mogił, tradycyjnych obyczajów. Autor nazywa je „historycznymi identyfikatorami”, a Pierre Norra „miejscami pamięci”.

Jan Assmann (2008) wyróżnia kilka „rodzajów” pamięci kulturowej: pamięć mimetyczną (obejmującą wzorce działań, których uczymy się przez naśladowanie), pamięć rzeczy (zwłaszcza rzeczy codziennego użytku, które mogą przypominać minione zdarzenia lub osoby) oraz pamięć zapisaną w języku, obecną w komunikacji międzyludzkiej, którą autor określa jako pamięć komunikatywną.

Przykładem pamięci mimetycznej, niejako zapisanej w obyczajach, w gestach, w codziennych sytuacjach, w których bierzemy udział obserwując innych i ucząc się od nich, może być zwyczaj z lat siedemdziesiątych i osiemdziesiątych zaobserwowany $\mathrm{w}$ dzielnicach zamieszkanych przez katolików: ostrzeganie sąsiadów przed nadchodzącymi oddziałami wojska brytyjskiego przez uderzanie w bruk ulicy blaszanymi pokrywami koszy na śmieci. Z kolei jako naśladowanie można określić zwyczaj wstępowania młodych mężczyzn do bojówek, zarówno lojalistycznych, jak i republikańskich — chłopcy szli w ten sposób w ślady ojców, braci, przyjaciół. Procesy enkulturacji do wzorca młodego bojownika/żołnierza walczącego i oddającego życie za słuszną sprawę zachodziły nie tylko na poziomie mezospołecznym, ale także $\mathrm{w}$ formie transmisji wzorów i norm kulturowych zawartych $\mathrm{w}$ piosenkach, opowieściach, wizerunkach bohaterów uwiecznionych na muralach, w końcu w filmach i literaturze.

Pamięć rzeczy dotyczy tego, co przypomina o konflikcie lub jego skutkach. Doskonałymi przykładami takich (szeroko rozumianych) rzeczy są oczywiście murale, flagi narodowe czy malowanie krawężników w narodowe barwy. Skła- 
dają się one na swoiste publiczne forum wyrażania poglądów i ideologii. Są to też rzeczy codziennego użytku, które w czasie trwania konfliktu zmieniły pierwotne zastosowanie, stając się „bronią” w walce: ręczne granaty robione z butelek, buty na platformach, w których przenoszono naboje, więzienne „bibuły" itp.

Pamięć o konflikcie zostaje zapisana w języku i sposobach komunikowania się. Bycie po którejś z walczących stron lub przypisanie do jednej z nich zmienia sposób komunikacji i postrzegania innych ludzi. Przejawia się to w upowszechnieniu pewnych zwyczajów (np. noszenie w butonierce żonkila w rocznicę powstania wielkanocnego, powszechne ukrywanie w prywatnych domach członków IRA lub uczestników zamieszek uciekających przed policją lub wojskiem), rytuałach grupowych (np. parady oranżystów czy marsze republikanów), stereotypach, wyzwiskach: (Prods i Taigs). Do pamięci komunikacyjnej należą wspomniane już opowieści o walce, piosenki patriotyczne, żarty z przeciwnika.

U Assmanna odnajdziemy też koncepcję pamięci zbiorowej, a w niej koncepcję „pamięci fundacyjnej” - ważny element procesów symbolicznego uprawomocnienia istnienia i trwania społeczności. Pamięć fundacyjna to pamięć podtrzymywana, legitymizowana i narzucana dzięki systemowi symboli tożsamości grupowej oraz rytuałów grupowych.

W przypadku lojalistów „aktem założycielskim” społeczności protestanckiej w Ulsterze, w sensie niemalże kosmicznym, a na pewno moralnym, jest postać-ikona Wilhelma Orańskiego (William III) i pamięć zwycięskiej bitwy nad rzeką Boyne (1690), która w ideologii (i mitologii grupowej) raz na zawsze ustaliła hierarchię i relacje władzy w Ulsterze. Interesujące są także próby „historycznego", czy raczej mitologicznego, osadzenia ulsterskich protestantów na terenie prowincji w czasach przed katolikami, aby — jak się wydaje - uniknąć niewygodnej roli tego, kto zjawił się „po” lub „później”. Celowi temu służy eksplorowanie postaci mitycznego $\mathrm{Cu}$ Chulainna ${ }^{2}$, powielanie jej na muralach, a przede wszystkim symbol Czerwonej Ręki (The Red Hand of Ulster) ${ }^{3}$. Pozwala to zakorzenić się w odległej, mitycznej przeszłości i potwierdzać prawo do bycia „tutaj”.

Konflikt etniczny stwarza szczególną sytuację, która wpływa na sposób funkcjonowania pamięci społecznej. Biorący w nim udział traktują wszelkie publiczne afirmacje tożsamości etnicznej jako potencjalną „broń w walce”. W sferze publicznej nie ma wówczas miejsca na wielogłos pamięci, obowiązuje jeden (dominujący) ton. Pamięć i afirmacje pamięci zostają zdominowane przez tych

${ }^{2} \mathrm{Cu}$ Chulainn, epicki bohater tzw. cyklu ulsterskiego Tain Bo Cualigne (polskie tłumaczenie autorstwa Ernesta Bryla i Małgorzaty Goraj, 1983), bronił Ulsteru przez zakusami (i najazdami) ze strony pozostałych czterech królestw prehistorycznej celtyckiej Irlandii: Connacht, Mumu (współczesny Munster), Laigin (dzisiejszy Leinster) oraz Mide (siedziba najwyższego króla).

${ }^{3}$ Symbol związany z osobą i legendą Cu Chulainna, konotujący prawo pierwszeństwa do zamieszkiwania i władania Ulsterem; współcześnie występujący w ikonografii zarówno lojalistów, jak i republikanów. 
członków społeczności, którzy jako jej dysponenci są w stanie narzucić reszcie społeczności swoją wolę i wizję przeszłości.

Jeśli pamięć społeczna staje się takim „narzędziem w walce”, to jest poddawana manipulacji. Osoby uznające siebie za dysponentów pamięci (często za pośrednictwem instytucji, organizacji, zrzeszeń) tworzą wzorce pamięci. Decydują, co i jak należy pamiętać (a tym samym, co i kto zostanie zapomniany). Narzucone zostają także wzorce upamiętniania - sposoby, formy publicznej afirmacji pamięci, kulturowo uprawomocnione w danej grupie. Mogą one zawierać odwołania do uznawanych za tradycyjne rytuałów grupowych) (Szczecińska-Musielak 2014).

\section{KATOLICY I PROTESTANCI — TOŻSAMOŚCI UWIKŁANE W KONFLIKT}

Tożsamości etniczne północnoirlandzkich katolików i protestantów są zbudowane na konflikcie i konfrontacyjne względem siebie. W obu ważną zmienną jest przekonanie o wspólnocie krwi (protestanci definiują siebie jako Brytyjczyków, a węziej jako potomków szkockich i angielskich osadników, katolicy zaś jako Irlandczyków — żaden protestant nie nazwie siebie „Irlandczykiem”).

Kolejną zmienną odgrywającą dużą rolę w procesach tożsamościowych obu grup jest terytorium, ojczyzna. Zarówno jedna, jak i druga grupa uzurpuje sobie prawa - nie tylko formalne, ale także symboliczne - do jej posiadania i użytkowania. Dla Irlandczyków Ulster jest integralną częścią wyspy i dlatego powinien wrócić „do macierzy”, gdyż jego oderwanie od Republiki Irlandii było efektem gry politycznej prowadzonej przez ulsterskich lojalistów. Ci drudzy łączą historię Ulsteru $z$ historią Brytanii, a Zakon Orański ${ }^{4}$ jako ruch społeczny umiejscawiany jest w szerszym kontekście angielskiego imperializmu i kolonializmu (Ruane, Todd 1993, s. 181). Jednakże do kanonu symbolicznego obu wspólnot weszły elementy celtyckiego dziedzictwa, jak The Red Hand of Ulster (symbol klanu O’Neillów, a także nazwa jednej z bojówek lojalistów; w latach 1953-1972 jeden z symboli umieszczanych na oficjalnej fladze Ulsteru) czy postać $\mathrm{Cu}$ Chulainna. Obie strony, republikanie i lojaliści, odwołują się do tych samych celtyckich symboli - dla lojalistów Czerwona Ręka jest symbolem oporu przez „najazdem” Irlandczyków, dla republikanów zaś walki z najazdem szkocko-brytyjskim. Podobnie interpretowana jest postać Cu Chulainna - dla republikanów stanowi symbol walki z „brytyjskim” najeźdźcą, a dla lojalistów walki i obrony przed „najazdem” z południa wyspy. W najwyższym stopniu ową

\footnotetext{
${ }^{4}$ Zakon Orański powstał w 1795 roku w Armagh w celu upamiętnienia i uhonorowania historycznego zwycięstwa protestanta Wilhelma Orańskiego nad katolikiem Jakubem II, a rok później odbyła się pierwsza parada upamiętniająca zwycięstwo nad Boyne. „Oranżyści”, sami protestanci, co roku 12 lipca organizują uroczyste parady upamiętniające to zwycięstwo, które daje im prawo do „posiadania” Ulsteru. Parady oranżystów często przechodziły przez katolickie dzielnice miast, co prowadziło do zamieszek, zwłaszcza w latach sześćdziesiątych i siedemdziesiątych XX wieku (zob. Szczecińska-Musielak 2012).
} 
tożsamość określa i kształtuje swoista, grupowa interpretacja historii i kultury „regionu”. Stąd autoidentyfikacja i etnonimy - Ulstermen - Ulsterczycy, czy ulsterness - ulsterskość, na przykład stosowanie przez polityków unionistycznych określen the Ulster people, a nawet the people, wyłącznie w odniesieniu do protestantów (Finlayson 1997, s. 81). Niektórzy badacze rozróżniają społeczności regionalnie i terytorialnie, na przykład „Ulsterczyków” (Ulstermen) i „Irlandczyków” (Irishmen), lub wprowadzają element topograficzny do tego rozróżnienia (tzn. zwracający uwagę na nazwy małych wsi, ulic itp.) (McGarry, O'Leary 1995, s. 219, 230).

Inną zmienną był i jest język (choć obecnie ma to znaczenie raczej symboliczne niż użytkowe). Rangę symbolu ma język irlandzki, gaelick, którego znajomość jest jednym z elementów samodefinicji katolika. Używanie go, zwłaszcza w miejscach publicznych, jest wyrazem przynależności do irlandzkiej, katolickiej wspólnoty oraz sprzeciwu wobec dyskryminacji tej mniejszości. Z kolei protestanci posługują się językiem ulster-scots. Jednak podstawową funkcję komunikacyjną pełni angielski - i to na całej wyspie (zob. np. McGarry, O’Leary 1995, s. 220-223).

Konflikt trwający od czasu siedemnastowiecznej Plantacji ${ }^{5}$ zaostrzyło prawne i faktyczne oderwanie sześciu hrabstw Ulsteru od powstającej na początku XX wieku Republiki Irlandii. Irlandczycy zarazem uzyskali wówczas niepodległość i utracili na rzecz odwiecznego wroga i okupanta znaczną część rodzimej ziemi (1920). Jednakże mechanizm odróżniania swojego od obcego, Irlandczyka od Brytyjczyka, wyłonił się dużo wcześniej, w XIII i XIV wieku, a kluczowa okazała się religia. Obie zmienne — religia i pochodzenie etniczne/krew — stały się głównymi elementami tożsamości etnicznych, a granice między grupami etnicznymi i jednocześnie głównymi aktorami konfliktu były bardzo wyraziste. Jest to widoczne między innymi w etykietkach „protestant” i „katolik”, jakie nadają sobie nawzajem, a także przeciwnikom, obie strony.

Warto pamiętać, że katolicy w Irlandii Północnej stanowią wspólnotę zintegrowaną i scentralizowaną w jeden Kościół — rzymskokatolicki. Protestanci rozdzieleni są pomiędzy wiele wspólnot religijnych. Określenie „kościoły” wydaje się adekwatne, gdyż oprócz Kościoła rzymskokatolickiego i największych wspólnot protestanckich (prezbiterianie i anglikanie) działa tu około 45 odrębnych wyznań (Morrow 1995, s. 156). Wspólnota rzymskich katolików jest liczebnie największa. Jednak siła i waga religii wynika, zdaniem Alana Finlaysona (1997, s. 84), z tego, że stanowi ona wyraźny znak grupy etnicznej i jej aspiracji — w przypadku Irlandii Północnej religia definiuje historycznie ugrun-

\footnotetext{
${ }^{5}$ Nazwa „Plantacja” (Plantation) występuje w literaturze przedmiotu jako określenie siedemnastowiecznej angielskiej polityki wobec podbitej Irlandii; jest to czas wysiedlania katolickich właścicieli ziemskich oraz intensywnego, masowego osiedlania się na północy wyspy szkockich prezbiterian, „lojalnych poddanych korony”, w zamierzeniu mających kulturowo i politycznie zdominować „nielojalnych” irlandzkich katolików.
} 
towany rdzeń etniczny, wokół którego krystalizowała się tożsamość społeczności.

Tożsamość protestantów Ulsteru często bywa określana jako „tożsamość twierdzy", tożsamość w stanie permanentnego oblężenia (siege identity) — jest to cecha grupy, która jednocześnie musi bronić swoich praw do życia na tej ziemi, praw do Ulsteru i „prawdziwej wiary” przed wrogimi papistami z południa wyspy. Tymczasem tożsamość katolików z północy wyspy to tożsamość społeczności przez wieki znajdującej się w ucisku, ludzi, którzy na swojej ziemi nie mieli żadnych praw, ludu zniewolonego i uciskanego politycznie, religijnie i gospodarczo - dlatego odnajdujemy w niej martyrologiczne rysy wzmacniane przez odwołania religijne.

Utworzenie Irlandii Północnej, zdominowanej politycznie i kulturowo przez brytyjskich protestantów, funkcjonowanie opresyjnego względem katolików aparatu władzy i sił porządkowych, pogłębiało podziały i wzajemną wrogość, wzmacniając konfrontacyjny i konfliktowy charakter obu tożsamości etnicznych. Ważną rolę w budowaniu wzajemnej wrogości odegrały bojówki paramilitarne: Irlandzka Armia Republikańska (IRA) po stronie katolików oraz Ulster Volunteer Force i Ulster Defence Association po stronie protestantów. O tym, jak silny był to wpływ, można się przekonać spacerując po katolickiej Falls Road czy protestanckiej Shankill Road w Belfaście i oglądając murale, które są symboliczną afirmacją dominującej w społeczności narracji tożsamościowej, kontrolowanej i narzucanej „swoim” i „obcym” przez byłe i obecne grupy paramilitarne zarówno po stronie republikańskiej, jak i lojalistycznej (Rolson 1992; Szczecińska-Musielak 2014a, 2015).

Elementem własnego wizerunku — jednostki lub grupy — jest także wizerunek antagonisty. Mimo wielu inicjatyw pokojowych w obrębie obu społeczności mających na celu wzajemne poznanie się i naukę tolerancji nadal funkcjonują niezwykle silne stereotypy. „Typowy” Irlandczyk to katolik, pijak, leń, nielojalny „Paddy” - od popularnego imienia Patryk (np. Ruane, Todd 1996, s. 182, 184). Z kolei "typowy” protestant to zadufany w sobie i w siłę brytyjskiego imperium „oranżysta” (członek Zakonu Orańskiego), nienawidzący katolików i obawiający się ich człowiek, który nie potrafi wyjść poza narzucone mu schematy, zwolennik siłowych rozwiązań.

Trwający dziesięciolecia proces rozmów i ustaleń między aktorami politycznymi i paramilitarnymi: reprezentującymi katolików Sinn Féin i IRA a przedstawicielami kolejnych brytyjskich rządów, doprowadził do nowego podziału władzy (Dixon 2001). Po dziesięcioleciach walk, ataków terrorystycznych, podkładania bomb, obecności wojska brytyjskiego, obostrzeń w poruszaniu się po ulicach miast, ofiar po obu stronach nadszedł czas upragnionego spokoju. Jednak zmiany polityczne, nawet trwający dziesiątki lat proces pokojowy, następują szybciej niż zmiany w postawach i światopoglądzie ludzi w ów konflikt uwikłanych. Powstają pytania o istotę tych przemian. 
Czy zmiany polityczne i systemowe rzeczywiście mają na celu współżycie głównych grup etnicznych/aktorów społecznych, stworzenie społeczeństwa Irlandii Północnej nie tylko z nazwy, czy jest to inna, nowa formuła walki - tym razem stricte politycznej — o niezmieniający się cel, czyli powrót Ulsteru do „macierzy” w przypadku republikanów?

Niezależnie od jawnych i ukrytych celów polityków większość mieszkańców Ulsteru chciała zakończenia konfliktu zbrojnego, bezpiecznego i spokojnego, w pewnym sensie normalnego życia. Musi to jednak pociągać za sobą istotne zmiany, między innymi dzielenie się władzą, przestrzenią, możliwościami życiowymi (do tej pory zarezerwowanymi dla protestantów), co w konsekwencji prowadzi do przedefiniowania wzajemnych postaw oraz tożsamości grupowych obu głównych aktorów społecznych. Jak przebiega to w praktyce?

\section{POLITYKA REKONCYLIACJI I SHARED FUTURE}

Dzięki postanowieniom podpisanego w 1998 roku Porozumienia Wielkopiątkowego (Good Friday Agreeement) o przyszłości Irlandii Północnej mieli zadecydować jej obywatele, oba rządy — brytyjski i irlandzki - zrezygnowały ze swoich roszczeń. Miał powstać nowy rząd północnoirlandzki, w którym poszczególne ministerstwa przypadłyby poszczególnym partiom (w tym także Social Democratic and Labour Party [SDLP] i Sinn Féin) proporcjonalnie do wyników wyborów. Interesy mniejszości miały być chronione przez ciało złożone z przedstawicieli władz północy i południa wyspy, o szerokich uprawnieniach (North-South Ministerial Council). Policja Ulsteru (RUC) miała zostać poddana radykalnej przemianie, czemu służyło powstanie komisji ds. policji, czuwającej nad zapewnieniem proporcjonalnego udziału obu społeczności w siłach porządkowych. W ciągu dwóch lat planowano uwolnienie więźniów politycznych. Porozumienie oznaczało także całkowite rozbrojenie organizacji paramilitarnych. W celu poprawy relacji między dwiema społecznościami utworzono wiele ciał, takich jak Human Rights Comission, Equality Comission czy Northern Ireland Victims Comission, a także przyjęto Bill of Rights for Northern Ireland, sformułowane na bazie europejskiej konwencji praw człowieka.

Porozumienie Wielkopiątkowe zostało przyjęte przez obywateli Irlandii Północnej w trybie referendum: przy wysokiej frekwencji (81\%) $71,1 \%$ głosujących poparło porozumienie, a $28,8 \%$ je odrzuciło (Dixon 2001, s. 273). W Republice Irlandii porozumienie zostało zaakceptowane, także na drodze ogólnonarodowego referendum. Konsekwencją tego faktu było wykreślenie w 1999 roku z konstytucji tego kraju artykułów 2 i 3, które mówiły, że „terytorium narodowe obejmuje całą wyspę Irlandię, jej wyspy i morza terytorialne" (Constitution of Ireland, 1937). Główni architekci porozumienia, David Trimble (UUP) i John Hume (SDLP), w 1998 roku otrzymali pokojową Nagrodę Nobla.

W 2006 roku rządy brytyjski i irlandzki oraz największe partie Irlandii Północnej podpisały St. Andrews Agreement. Porozumienie z jednej strony doty- 
czyło pełnego wsparcia ze strony Sinn Féin dla procesu dewolucji sądownictwa i systemu prawa oraz sił policyjnych. $Z$ drugiej strony zapewniało partiom republikańskim udział $\mathrm{w}$ rządzie. W efekcie utworzono dwa równorzędne stanowiska — rząd Irlandii Północnej jest kierowany przez dwóch premierów, pochodzących z dwu zwycięskich (w wyborach powszechnych) partii: First Minister i Deputy First Minister. Podział mandatów i miejsc w parlamencie opiera się na ustaleniach $z$ St. Andrews. Po raz pierwszy od powstania Irlandii Północnej mniejszość katolicka, poprzez swoich demokratycznie wybranych reprezentantów, zyskała wpływ na realną władzę w zakresie polityki wewnętrznej. Polityka dewolucji (devolution of policing and justice to Belfast) doprowadziła do utworzenia nowego rządu, w którym teki ministerialne otrzymali przedstawiciele nacjonalistycznych partii katolickich. Realną zmianą jest także rozwiązanie sił policyjnych RUC i zastąpienie ich Northern Ireland Policing Service, w których udział mają także policjanci wywodzący się z mniejszości katolickiej.

Poważnym problemem były i nadal są przemarsze oranżystów, których trasy i forma budzą kontrowersje i sprzeciwy katolickiej mniejszości. Strony konfliktu doszły do porozumienia (tzw. Hillsborough Castle Agreement, luty 2010 ro$\mathrm{ku}$ ), godząc się, aby trasy marszów były — po negocjacjach — ustalane i kontrolowane przez specjalną komisję (The Parades Commission). Jednak działalność tej komisji spotyka się z ostrą krytyką ze strony organizacji lojalistycznych. Bardzo często zmiany tradycyjnych tras parad oranżystów prowadzą do zaostrzania konfliktu i zamieszek.

Nadrzędnym celem parlamentu — Zgromadzenia Północnoirlandzkiego (Northern Ireland Assembly) oraz rządowej administracji jest kreowanie warunków politycznych sprzyjających promowaniu i podejmowaniu konkretnych działań, programów mających na celu wprowadzanie zmian nie tylko politycznych i ustawodawczych, lecz także instytucjonalnych, które służyłyby poprawie warunków życia mniejszości katolickiej oraz wypracowywaniu wspólnych strategii rozwojowych: gospodarczych i społecznych. Nadrzędnym dokumentem o kluczowym znaczeniu, definiującym strategię władz północnoirlandzkich, jest przygotowany przez rząd i opublikowany w marcu 2005 roku A Shared Future - Policy and Strategic Framework for Good Relations in Northern Ireland. Zawiera on deklarację woli budowania poprawnych relacji między obiema społecznościami i podkreśla znaczenie, jakie przywiązują do tego nowe władze północnoirlandzkie. Celem jest zbudowanie obywatelskiego shared society, opartego na równości i inkluzji oraz promowaniu dobrych relacji między wszystkimi społecznościami zamieszkującymi Ulster. Program Shared Future sięga do rządowego (Office of the First Minister and Deputy First Minister, OFMDFM) raportu z 2001 roku: Community Relations Policy, który stanowi część strategii Programme for Government z 2001 roku, a także pośrednio do opublikowanego w 2003 roku przez OFMDFM dokumentu A Shared Future: On Improving Relations in Northern Ireland. Wymienione dokumenty rządowe miały na celu zakreślenie szerszych ram polityki wewnętrznej, skupionej na walce z przejawami 
(także wizualnymi - flagi, emblematy, muralsy itp.) religijnych, etnicznych i rasowych uprzedzeń i ataków (w lipcu 2005 roku administracja rządowa opublikowała Racial Equality Strategy).

W czerwcu 2006 roku OFMDFM podało do publicznej wiadomości plan na lata 2006-2009, zatytułowany Making It Happen - Implementing the Policy and Strategic Framework for Good Relations in Northern Ireland. Jednym z priorytetów było usuwanie - we współpracy z władzami lokalnymi i społecznościami sekciarskich i rasistowskich murali, flag, graffiti z budynków użyteczności publicznej oraz czyszczenie krawężników malowanych w barwy bojówek. W przekonaniu autorów polityki shared future podziały i napięcia między społecznościami żyjącymi na terenie Irlandii Północnej w znaczącym stopniu utrudniają rozwój zarówno gospodarczy, jak i społeczny, zwłaszcza na obszarach dotkniętych deprywacją i wykluczeniem społecznym. Poszczególne ministerstwa oraz organy administracji rządowej przyjęły wiele programów służących poprawie relacji, dotyczących różnych sfer współdziałania społecznego, między innymi program rządowy na lata 2008-2011 (The Executive's Programme for Government). W 2000 roku władze Wielkiej Brytanii zainicjowały dziesięcioletnią strategię odnowy i rewitalizacji trzech tysięcy najbiedniejszych społeczności lokalnych, określaną jako Neighbourhood Renewal, obejmującą modernizację domów, poprawę świadczeń zdrowotnych, walkę z przestępczością oraz kreowanie nowych miejsc pracy. W 2002 roku północnoirlandzki Department of Social Development (DSD) zainicjował konsultacje Urban Regeneration in Northern Ireland, a w 2003 roku na ich podstawie uruchomiono nową strategię renowacji i regeneracji najbardziej zniszczonych miejskich przestrzeni lokalnych.

Interesująca $\mathrm{w}$ powyższym kontekście była inicjatywa Re-imagining Communities Programme, realizowana pod egidą Arts Council of Northern Ireland (zob. Evaluation of the Re-imagining Communities Programme: A Report to the Arts Council of Northern Ireland Independent Research Sollutions 2009). Celem tego programu była zmiana lokalnego obrazu grupowych tożsamości i identyfikacji, symbolicznie wyrażanego na murach (murals). Animatorzy programu starali się zachęcać lokalne społeczności, między innymi w drodze negocjacji społecznych z mieszkańcami oraz współpracy z lokalnymi władzami, do wyrażania tożsamości grupowej w inny niż do tej pory sposób, pokojowy i nieagresywny, przez odwołania do symboli grupowych, które mieszkańcom nie kojarzą się jednoznacznie z walką czy przemocą. Program rozpoczął się w 2006 roku i trwał około trzech lat. Był skierowany przede wszystkim do społeczności lokalnych dotkniętych deprywacją. Z jednej strony celem było usuwanie z publicznej przestrzeni obrazów propagujących sekciarskie lub rasistowskie uprzedzenia i zamienianie ich na obrazy o treści „pozytywnej, włączającej i nie odstraszającej”, z drugiej - renowacja, rewitalizacja wizerunku miejsca przez sprzątanie i czyszczenie przestrzeni publicznej, sadzenie drzew i krzewów, a także montowanie instalacji artystycznych. Zgłoszono 177 projektów, z czego 123 otrzymały granty. Budżet programu łącznie wyniósł ponad 3 mln funtów. 
Ważnym elementem były konsultacje społeczne, rozmowy z lokalnymi władzami oraz mieszkańcami terenów objętych programem, a także lokalnymi artystami, wykonawcami nowych malowideł lub instalacji, długotrwałe i wielostopniowe spotkania, fokusy i wywiady, w trakcie których wspólnie uzgadniano treść i formę, a także symbole umieszczane na nowych muralsach. Interesujące jest to, że animatorom programu udało się zaangażować te grupy, które w dotychczasowym dyskursie ideologicznym zajmowały marginalne pozycje — dzieci i młodzież oraz kobiety. W ten sposób nowe muralsy stały się symbolicznym środkiem wyrazu i zarazem komunikatem wysyłanym przez grupy dotychczas zmarginalizowane i pozbawione prawa głosu w kwestiach uznanych za „sprawy wojenne".

Znakiem nowych czasów i procesu pokojowego jest także otwarcie centrum Belfastu dla publicznej działalności grup, które wcześniej nie mogły korzystać $z$ tej przestrzeni, zarezerwowanej dla reprezentantów grupy dominującej, ulsterskich protestantów. W sierpniu 1993 roku Republican Internment Commemoration Parade (odbywająca się corocznie parada upamiętniająca internowanych republikanów) uzyskała pozwolenie na przejście przez centrum miasta, a Gerry Adams (lider Sinn Féin) wygłosił przemówienie przed ratuszem, stojąc obok pomnika Królowej Wiktorii. Od 1998 roku przez centrum miasta przechodzą parady na dzień św. Patryka. Co ciekawe, po kilku latach (i długich negocjacjach) władzom miejskim udało się przekształcić to pierwotnie katolickie i irlandzkie święto w Festiwal Świętego Patryka (St. Patrick's Festival), otwarty nie tylko dla katolików, ale i dla protestantów oraz mniejszości imigranckich osiedlających się w Belfaście. Od 2005 roku jest organizowany przez Radę Miejską, a maszerujący otrzymują wielokolorowe koniczynki (zamiast tradycyjnych barw flagi Republiki Irlandii) oraz t-shirty $z$ logo miasta.

Lee A. Smithey twierdzi (2009), że w ostatnich latach także zmieniło charakter sztandarowe, nomen omen, dla brytyjskiej i lojalistycznej tożsamości Ulsterczyków (protestantów) wydarzenie „The Twelfth”, parada oranżystów 12 lipca. Afirmację militarnego i antykatolickiego wymiaru tożsamości lojalistycznej zastąpiły bardziej przyjazne i bezpieczne dla rodzin odwołania do lokalnych tradycji kulturowych, zwłaszcza muzycznych, w formie zabaw i konkursów.

Otwierane są więc nowe-stare przestrzenie, zarówno te fizycznie istniejące, jak i duchowe - służą wzajemnemu poznaniu i nawiązaniu relacji. Budowanie „mieszanych” osiedli mieszkaniowych pozwala na sąsiedzkie funkcjonowanie w toku codziennego użytkowania przestrzeni. Równie ważne jest otwieranie ważnych społecznie przestrzeni, jak centrum miasta, dla grup, które do tej pory nie mogły z nich swobodnie korzystać. Wydaje się, że tego rodzaju działania oraz strategia shared future stanowią poważny krok naprzód, są początkiem i jednocześnie podstawą, na której można budować coś nowego, nowy rodzaj relacji etnicznych i społecznych w Irlandii Północnej. Ważnym elementem tej strategii jest polityka rekoncyliacji, pojednania, potrzebna obu stronom kon- 
fliktu zarówno do uświadomienia sobie własnych win względem drugiej strony, jak i do publicznego wyrażenia swoich przewinień. Wydaje się, że proces pojednania i budowania „wspólnej przyszłości” nie jest możliwy bez duchowego i moralnego zaangażowania członków obu społeczności, zmiany postaw.

\section{WOJENNE/KONFLIKTOWE TOŻSAMOŚCI ETNICZNE A PROCES POKOJOWY}

Sądzę, że do rzeczywistego budowania „wspólnej przyszłości” jest niezbędna rekonstrukcja etnicznych tożsamości głównych aktorów konfliktu. Wydaje się, że proces ten, zwłaszcza w przypadku tożsamości grupowych, ma większe szanse powodzenia, jeśli jest zapoczątkowany i/lub zaakceptowany przez liderów - zarówno przywódców uznawanych za przedstawicieli (także politycznych) całej społeczności, jak i lokalnych liderów danych sąsiedztw. Inicjatywy czy podejmowane działania mogą zapoczątkowywać ci liderzy lub poszczególne jednostki, mieszkańcy i obywatele Ulsteru w formie ruchów i działań „oddolnych". Najważniejszym zadaniem jest przedefiniowanie tożsamości tak, aby były bardziej afirmacyjne, a mniej konfrontacyjne. Następnie należy przekonać do owych zmian, fundamentalnych przecież, samych zainteresowanych, a więc członków społeczności katolickiej i protestanckiej.

Podczas pobytu badawczego w Belfaście w październiku 2013 roku byłam świadkiem debaty telewizyjnej w Ulster TV na temat obchodów dwudziestej rocznicy republikańskiego ataku terrorystycznego na sklep rybny Frizzel's przy lojalistycznej Shankill Road (tzw. Shankill Bombing). W wyniku wybuchu bomby zginęło wówczas jedenaście osób. W studiu spotkali się nie tylko dziennikarze i komentatorzy, ale także przedstawiciel jednej z zamordowanych rodzin Charlie Butler (stracił troje krewnych) oraz katolik Mark Rodgers, którego ojciec został zastrzelony przez bojówkę lojalistyczną w odwecie za atak na sklep. Obaj panowie bardzo szczerze i odważnie opowiadali o swoich odczuciach i cierpieniu po stracie bliskich, tym dotkliwszym, że byli oni de facto przypadkowymi ofiarami ataków bojówek paramilitarnych — nad sklepem Frizzel's spotykali się czasami przywódcy lojalistycznej organizacji paramilitarnej Ulster Freedom Fighters (UFF), a bombę w sklepie podłożyli członkowie IRA (jeden $z$ nich zginął na miejscu). W pewnym momencie obaj panowie podeszli do siebie i podali sobie ręce, uznając nawzajem swoje straty. Tydzień później, bez asysty mediów, wspólnie pojechali do miejscowości Greysteel, gdzie złożyli kwiaty w miejscu odwetowego ataku terrorystycznego - w miejscowej restauracji członkowie UFF zastrzelili wówczas bawiących się w sobotni wieczór katolików. Wydaje się, że tego rodzaju przekraczanie etnicznych i „wojennych” granic, wymagające w realiach Irlandii Północnej sporej odwagi osobistej, w jakimś stopniu wpłynęło na postawy osób zaangażowanych we wspólne upamiętnienie ofiar. Wytworzyło nową płaszczyznę relacji między nimi i ich rodzinami.

Podczas podjętego wówczas badania terenowego mogłam obserwować w sobotnie przedpołudnie cotygodniowy protest grup lojalistycznych przeciw- 
ko decyzji rady miejskiej Belfastu o zdjęciu flagi Zjednoczonego Królestwa ${ }^{6}$. Protestujący mieli flagi i banery z motywem flagi brytyjskiej, w kulminacyjnym punkcie pikiety było to około czterdziestu osób, głównie mężczyzn, w tym młodych. Sytuacja miała wyraźnie pokojowy, wręcz towarzyski charakter (kolejni protestujący byli witani brawami, serdecznie ściskani, sprawiało to wrażenie spotkania osób dobrze się znających), wzbudzała też niewielkie zainteresowanie przechodniów (głównie moje i nielicznych turystów). Niewielu kierowców mijających protestujących klaksonem dawało wyraz swojego poparcia dla słusznej, ich zdaniem, idei. Protestujących pilnowało kilkunastu policjantów w równie pokojowych i rozluźnionych nastrojach. Na flagach i banerach widniały napisy „bastionów” lojalizmu Belfastu: Sandy Row, Lower Shankill, Loyalist Blackskull, Village/Donegall Road.

Oznaką zmian we wzajemnych postawach katolików i protestantów może być masowe uczestnictwo w paradach i marszach niegdyś o charakterze wyraźnie etnicznym, obecnie otwartych dla wszystkich mieszkańców. Jak już wspomniałam, od 1998 roku przez centrum Belfastu w dniu św. Patryka przechodzą parady. Sondaż przeprowadzony podczas festiwalu w 2008 roku ujawnił interesujące dane - badani wyrazili zadowolenie $z$ braku flag narodowych (irlandzkiej i brytyjskiej), podkreślając, że ma to być wydarzenie przeznaczone dla wszystkich mieszkańców miasta ${ }^{7}$. Jest to interesujący przykład swoistego redefiniowania wydarzenia, a nawet symbolu, bardzo mocno kojarzonego $z$ irlandzkością czy republikanizmem, i obdarzania go nowym, lokalnym znaczeniem - niegdysiejsze republikańskie święto i paradę $z$ wpisano w kalendarz wydarzeń miejsko-obywatelskich.

Podobnie stało się z innym wydarzeniem, Lord Major's Show, paradą organizowaną przez urząd burmistrza Belfastu. Początkowo, w latach sześćdziesiątych, była to okazja do zaprezentowania lokalnych przedsiębiorstw oraz organizacji charytatywnych, a także firm z południa Irlandii, z Republiki. W czasie „Kłopotów” zrezygnowano $z$ tego wydarzenia, a po powrocie do kalendarza miejskich imprez zupełnie zmieniło ono charakter, dotychczas komercyjny. Miejsce przedsiębiorstw i firm, biznesu i korporacji zajęły wystawy i prezentacje mniejszości i grup etnicznych zamieszkujących Belfast, między innymi mniejszości chińskiej (w 1998 roku wśród demonstrowanych symboli pojawiły się

\footnotetext{
${ }^{6}$ Swoistą odpowiedzią, czy kontratakiem, na uroczyste obchody antyirlandzkiego, czy raczej antyrepublikańskiego, wydarzenia historycznego, jakim była setna rocznica podpisania Solemn League and Covenant (październik 2012) było głosowanie w miejskim ratuszu w Belfaście nad zdjęciem z jego fasady brytyjskiej flagi (6 grudnia 2012). Sinn Féin i SDLP zgłosiły propozycję zdjęcia flagi, natomiast Alliance Party zaproponowała kompromis polegający na tym, że flaga zostanie zdjęta, ale będzie wywieszana w czasie dni świątecznych, przez siedemnaście wybranych dni w roku. Ta ugodowa propozycja została uchwalona w wyniku głosowania. Kilka minut później City Hall zaatakowała grupa kilkuset protestujących lojalistów. Zamieszki w mieście, inspirowane i kierowane przez lojalistyczne bojówki, trwały przez kilka dni.

7 Informacji o badaniu udzielił dr Dominik Bryan.
} 
chińskie smoki). W 1998 roku imprezę prowadził pierwszy republikański burmistrz Belfastu, Alban Maginnes z SDLP. W dziesięć lat później nadano jej nową nazwę Belfast Carnival, obecnie jest to przestrzeń służąca prezentacji i reprezentacji artystycznych, multikulturowych inicjatyw i wydarzeń. Od 1991 roku w ramach multikulturowego karnawału odbywają się parady gejów i lesbijek. W 1982 roku zainicjowano maratony z udziałem biegaczy katolickich i protestanckich (zob. Bryan, Gillespie 2005).

W przestrzeni publicznej - na ulicach, w parkach, instytucjach publicznych - można dostrzec zmianę $\mathrm{w}$ sposobach prezentowania symboli etnicznych, emblematów oraz innych form wizualnej etnoidentyfikacji (Szczecińska-Musielak 2015). Oczywiście, nieroztropne byłoby spodziewać się, że owe zmiany będą miały charakter totalny, że pojawią się zupełnie nowe „projekty tożsamościowe”, należy raczej oczekiwać przesunięcia akcentów w istniejących konfiguracjach tożsamościowych, podkreślania pozytywnych, niekonfrontacyjnych elementów.

Wydaje się, że tak się stało w przypadku wspomnianego już programu Re-Imagining Community Programme, w ramach którego zmieniono mural znajdujący się u szczytu Sandy Row, jednej z najbardziej lojalistycznych ulic Belfastu. Wcześniej na ścianie budynku widniały ogromne napisy: You are now entering loyalist Sandy Row, Heartland of South Belfast Ulster Freedom Fighters. Obecnie w tym miejscu znajduje się portret Wilhelma Orańskiego oraz niezwykle ważnej dla ulsterskich protestantów daty bitwy nad Boyne, a pod wizerunkiem protestanckiego króla napis „wojska Wilhelma”, wśród których wymieniono także Polaków. Ta zmiana treści, z przekazu agresywnego i sekciarskiego na nadal lojalistyczny w duchu, ale zdecydowanie spokojniejszy i bardziej neutralny, może być zinterpretowana jako próba redefinicji tożsamości grupowej, pozostająca w ważnych i z punktu widzenia członków grupy niezbędnych granicach. Do takiej interpretacji upoważnia fakt, że wszystkie zmiany murali były dyskutowane i negocjowane $z$ lokalnymi mieszkańcami, że nie niszczono ich później czy nie zamalowywano, można więc założyć, że spotkały się ze zgodą i akceptacją zainteresowanych.

Szczególną rolę $\mathrm{w}$ procesie rekoncyliacji oraz przedefiniowywania tożsamości etnicznych odgrywają Kościoły oraz organizacje religijne: The Irish Council of Churches, Irish Commission for Justice and Peace, Protestant and Catholic Encounter (Pace) (zob. Szczecińska-Musielak 2014b). Kościoły i organizacje chrześcijańskie, podkreślając różnice religijne między protestantami a katolikami, jednocześnie uczą swoich członków nieagresywnego i niekonfrontacyjnego wyrażania własnych poglądów i przekonań religijnych.

Nie mniej ważne są oddolne inicjatywy, działania lokalnych grup stawiających sobie za cel pojednanie i ułożenie na nowo dobrych stosunków sąsiedzkich. Największą tego rodzaju inicjatywą jest The Conymeela Community (CC), skupiająca około dwustu uczestników i oferująca wiele różnych programów - rocznie z centrum CC korzysta około dziewięciu tysięcy osób. Na 
mniejszą skalę działają inne organizacje lokalne skupiające członków z obu społeczności (cross-community): Bryson House, Community of the Peace People, East Belfast Community Group, Derry Peace and Recinciliation Group (zob. Love 1995). Tego rodzaju inicjatywy prowadzą do wytwarzania przestrzeni społecznych, w których zachodzą - na razie w warunkach niejako „laboratoryjnych", wyabstrahowanych z codziennego rytmu życia i pracy - relacje międzygrupowe, co pozwala protestantom i katolikom spotkać się, poznać, porozmawiać i być może powoli zmieniać postawy względem siebie nawzajem.

Okazje do wspólnych spotkań są szczególnie ważne. Od początku istnienia Irlandii Północnej aż po lata osiemdziesiąte XX wieku obie społeczności dzieliła segregacja przestrzenna i społeczna. Jej konsekwencją był brak „naturalnych” indywidualnych kontaktów (w szkole, na podwórku, w miejscu pracy). $\mathrm{Z}$ tego też może wynikać zauważony (i doświadczany osobiście) przez niektórych badaczy (zob. Crozier 1989) brak „naturalnych” wspomnień, „naturalnej” pamięci biograficznej. Jednocześnie przez długie lata brakowało w programach szkolnych (na przykład z historii czy języka) wiedzy na temat „tej drugiej strony”, tym bardziej że dzieci i młodzież katolicka uczęszczały do prowadzonych przez Kościół katolicki voluntary schools, a dzieci i młodzież protestancka uczyły się i nadal się uczą w szkołach państwowych (state schools; zob. Morgan i in. 1996). Brakowało także programów nauczania w zakresie historii i kultury Ulsteru oraz dziejów poszczególnych społeczności lokalnych. Taki stan rzeczy sprawił, że wiedza katolików o protestantach i protestantów o katolikach pochodziła albo ze wspomnień dziadków lub rodziców, albo z lektury książek lub prasy, a także $z$ krążących stereotypów. W związku z tym pamięć wzajemnych relacji była pamięcią o zdarzeniach odległych czasowo lub o zamieszkach, atakach terrorystycznych. Wzmacniali i powielali ją ideolodzy polityczni, a także murale, parady, artykuły w społecznościowych gazetach.

Z pamięci zbiorowej obu społeczności przez długi czas wymazywano, wykluczano pamięć i wiedzę o przeciwniku (ale także o sąsiedzie). Sprawiło to, że obraz „ziemi własnej”, obraz Ulsteru tworzony, powielany i odtwarzany przez obie społeczności, był niepełny, a nawet kaleki. Trudno w takich warunkach kształtować nie odwołującą się do konfrontacji tożsamość etniczną. Dlatego kształtująca obecne relacje etniczne pamięć o wzajemnych relacjach, stosunkach etnicznych w dużej mierze jest pamięcią o konflikcie. Każda ze społeczności inaczej „zapamiętała” i interpretuje zdarzenia ważne dla historii, poczucia ciągłości i tożsamości etnicznej i kulturowej (imagined histories). W rezultacie nie ma porozumienia co do wspólnej oceny, wspólnego upamiętniania zdarzeń składających się na konflikt - występuje więc konflikt pamięci.

\section{ZAKOŃCZENIE}

Czy przedstawione przykłady oddolnych ruchów i instytucjonalnych programów można zinterpretować jako próby zmiany dotychczasowych postaw 
katolików i protestantów względem siebie? Wydaje się, że tak. Czy mogą zostać zinterpretowane jako próby przedefiniowywania „wojennych” tożsamości etnicznych, których oś stanowi konflikt i konfrontacja $z$ „wrogiem”? Sądzę, że tak - przy ostrożnym założeniu, że należy je traktować właśnie jako próby. Dostrzegam $\mathrm{w}$ powyższych działaniach zamiar wyrażania własnej tożsamości etnicznej i grupowej za pomocą innych niż dotychczas, mniej konfrontacyjnych, a bardziej koncyliacyjnych, publicznych środków wyrazu (przemalowane murale, „podzielenie się” świętem o dotychczas jednoznacznie etnicznym charakterze i zamiana go w święto otwarte dla wszystkich mieszkańców Belfastu, rządowy program powstania mieszanych osiedli). Jak wspomniałam, tworzenie okazji do spotkań katolików i protestantów, do podejmowania wspólnych działań w przestrzeni miejskiej i sąsiedzkiej jest bardzo ważnym elementem procesu pokojowego w kraju, w którym „posiadanie” terytorium - ulicy, budynku, dzielnicy czy osiedla - było jednym z powodów wzajemnej wrogości i agresji. W republikańskich czy lojalistycznych dzielnicach nadal zobaczymy krawężniki pomalowane w „barwy narodowe”, murale o zdecydowanie sekciarskim wyrazie, flagi i symbole narodowe Irlandii oraz Wielkiej Brytanii (zob. Szczecińska-Musielak 2015). Nie budzi to jednak zdziwienia antropologa ani socjologa, gdyż przemiany postaw i światopoglądów, relacji społecznych, zwłaszcza w powojennej/pokonfliktowej rzeczywistości, nie zachodzą szybko. Sądzę, że przebudowa wzorów tożsamości etnicznej to raczej długotrwały, wielopokoleniowy proces.

Szczególnym przykładem takiej zmiany jest życie i kariera republikańskiego działacza politycznego, zmarłego 21 marca 2017 r. Martina McGuinnessa. Jako dziecko z wielodzietnej katolickiej rodziny, zamieszkującej ubogą dzielnicę Bogside w Derry, obserwował bezpośrednio skutki polityki lojalistów względem katolickiej mniejszości, niepokoje i rozruchy na tle etnicznym oraz działania wojska brytyjskiego wobec protestujących katolików. Doświadczenia te zaprowadziły go do Irlandzkiej Armii Republikańskiej (w czasie „Krwawej Niedzieli" w 1972 roku był zastępcą dowódcy IRA), a później do jej politycznego skrzydła Sinn Féin. Martin McGuinness nigdy nie wyparł się związków z IRA, $z$ odsłoniętą twarzą wiele razy uczestniczył $\mathrm{w}$ publicznych pogrzebach „żołnierzy" republikańskiej bojówki. Był kojarzony z zamachami bombowymi oraz egzekucjami dokonywanymi przez IRA (choć nie ma na to bezpośrednich dowodów). Jednocześnie od lat osiemdziesiątych zaangażował się po stronie Sinn Féin w potajemne negocjacje pokojowe $z$ kolejnymi rządami brytyjskimi. Później jako lider IRA negocjował warunki rozbrojenia się tej organizacji oraz pokojowego podziału władzy w Irlandii Północnej. Zdeklarowany republikanin, którego z podczas wizyty Elżbiety II w Irlandii Północnej uwieczniono na zdjęciu, gdy ściskał dłoń królowej, zapytany po tym spotkaniu przez dziennikarzy, odparł krótko: still republican (nadal jestem republikaninem). Martin McGuinness wspólnie z Gerrym Adamsem po stronie republikanów byli głównymi architektami rozmów i ustaleń, które doprowadziły do Porozumienia Wielkopiąt- 
kowego. Przez wiele lat pełnił funkcję wicepremiera (Deputy First Minister), współpracując (spokojnie i owocnie) ze swoim ideologicznym wrogiem, lojalistą pastorem Ianem Paisley, kierował ministerstwami edukacji oraz zdrowia.

W styczniu 2017 roku zrezygnował z pracy w rządzie, z powodów zdrowotnych oraz „różnic nie do pogodzenia” między nim a sprawującą funkcję lojalistycznego premiera (Prime Minister) Arlene Foster. Jako swoją następczynię „namaścił” czterdziestoletnią działaczkę i posłankę republikańską, Michelle O’Neill. Ze względu na rezygnację McGuinnessa na mocy prawa wyborczego oraz ustaleń pokojowych konieczne były nowe wybory i na początku marca 2017 roku po raz pierwszy w historii zwycięstwo wyborcze odniosła republikańska partia Sinn Féin.

Można różnie oceniać karierę polityczną Martina McGuinnessa, można ujrzeć w niej także przykład wspomnianej wcześniej przemiany tożsamości etnicznej, grupowej. Przemiany będącej raczej swoistym przesunięciem akcentów niż rezygnacją $z$ fundamentów republikanizmu, $w$ tym przypadku irlandzkiego. Martin McGuinness zrezygnował $z$ walki zbrojnej, nie tylko jako formy osobistego zaangażowania, ale także — jako formy działania organizacji, której przewodził przez dziesięciolecia. Surowo przy tym ocenił i potępił wszelkie przypadki łamania postanowień pokojowych przez republikańskich dysydentów. Jednocześnie podstawowe wyznaczniki jego publicznie deklarowanej tożsamości - zjednoczenie wyspy i udział we władzach katolickiej mniejszości pozostały niezmienione.

\section{BIBLIOGRAFIA}

Assmann Jan, 2008, Pamięć kulturowa. Pismo, zapamiętywanie i polityczna tożsamość w cywilizacjach starożytnych, tłum. Anna Kryczyńska-Pham, Wydawnictwo Uniwersytetu Warszawskiego, Warszawa.

Bokszański, Zbigniew, 1989, Tożsamość Interakcja Grupa. Tożsamość jednostki w perspektywie teorii socjologicznej, Wydawnictwo Uniwersytetu Łódzkiego, Łódź.

Bokszański Zbigniew, 2005, Tożsamości zbiorowe, Wydawnictwo Naukowe PWN, Warszawa.

Bryan Dominic, Gordon Gillespie, 2005, Transforming Conflict: Flags and Emblems, Institute of Irish Studies, Queen's University, Belfast.

Crozier Maurna (red.), 1989, Cultural Traditions in Northern Ireland, Institute of Irish Studies, Queen's University, Belfast.

Dixon Paul, 2001, Northern Ireland: The Politics of War and Peace, Palgrave Macmillan, Basingstoke-New York.

Finlayson Alan, 1997, Discourse and Contemporary Loyalist Identity, w: Mark McGovern, Peter Shirlow (red.), Who Are the People?, Pluto Press, London.

Halbwachs Maurice, 2008, Społeczne ramy pamięci, tłum. Marcin Król, Wydawnictwo Naukowe PWN, Warszawa.

Isajiw Wsievolod, 1974, Definitions of Ethnicity, „Ethnicity”, nr 1, s. 111-124.

Jarymowicz Maria, 1992, Tożsamość jako efekt rozpoznawania siebie wśród swoich i obcych, w: Paweł Boski, Maria Jarymowicz, Hanna Malewska-Peyre (red.), Tożsamość a odmienność kulturowa, IP PAN, Warszawa.

Kula Marcin, 2004. Krótki raport o użytkowaniu historii, Wydawnictwo Naukowe PWN, Warszawa. 
Love Mervyn T., 1995, „Peace Building Through Reconciliation in Northern Ireland”, Avebury. McGarry John, O’Leary Brendan, 1995, Explaining Northern Ireland, Blackwell, Oxford.

Morrow Duncan, 1995, Church and Religion in the Ulster Crisis, w: Seamus Dunn (red.), Facets of the Conflict in Northern Ireland, St. Martin's Press.

Melchior Małgorzata, 1990, „Społeczna tożsamość jednostki (w świetle wywiadów z Polakami pochodzenia żydowskiego urodzonymi w latach 1944-1955)", Warszawa.

Nowicka Ewa, 1989, Etniczność a sytuacja mniejszościowa, „Przegląd Polonijny”, t. XV, z 1, s. 43-57.

Ricoeur 2006,

Rolson Bill, 1992, Drawing Support: Murals in the North of Ireland, Beyond the Pale Publications, Belfast (http://cain.ulst.ac.uk/bibdbs/murals/rolston1.htm).

Ruane Joseph, Todd Jennifer, 1993, 'Why can't you get along with each other?': culture, structure and the Northern Ireland conflict, w: Eamonn Hughes (red.), Culture and Politics in Northern Ireland 1960-1990, Philadelphia, Open University Press, Milton Keynes, s. 27-40.

Saryusz-Wolska Magdalena, 2010, Zapomnieć się w pamięci. Pytania o badanie pamięci kulturowej, „Kultura Współczesna", nr 1.

Smithey Lee A., 2009, Conflict Transformation, Cultural Innovation and Loyalist Identity in Northern Ireland, w: Marc Howard Ross (red.), Culture and Belonging in Divided Societes Contestation and Symbolic Landscapes, PENN, University of Pennsylvania Press.

Smith Anthony D., 2009, Etniczne podstawy narodów, tłum. Małgorzata Głowacka-Grajper, Wydawnictwo UJ, Kraków.

Szacka Barbara, 2006, Czas przeszty — pamięć - mit, Scholar, Warszawa.

Szczecińska-Musielak Ewa, 2014, Pamięć jako narzędzie walki w konfliktach etnicznych. Casus Irlandii Pótnocnej, „Politeja”, t. 31, nr 1, s. 483-504.

Szczecińska-Musielak Ewa, 2014a, „Religion and Church(es) in the Northern Ireland Peace Process”, w: „Bridging the Divides Post-conference publication on faith-based reconciliation and peacebuilding commemorating the 30th anniversary of 'Reconciliatio et paenitentia' by St. John Paul II and the Year of Jan Karski” (http://www.centrumjp2.pl/wp-content/uploads/ 2015/02/Bridging-the-Divides-Postconference-Publication.pdf).

Szczecińska-Musielak Ewa, 2015, Przemiany przestrzeni miejskiej Belfastu. Między konfliktem etnicznym a procesem pokojowym, Scholar, Warszawa.

\title{
WAR-RELATED ETHNIC IDENTITIES IN POST-CONFLICT SOCIETIES -THE CASE OF NORTHERN IRELAND
}

\author{
Ewa Szczecińska-Musielak \\ (Wszechnica Polska)
}

\section{Summary}

The author considers the situation prevailing in post-conflict societies, basing her reflections on the assumption that a key element of the peace process should be the formation (even if incomplete) of a model of group identity. As an example, she references the ethnic identities of the two main actors in the Northern Ireland conflict: the Irish Catholics and the Ulster Protestants. The decades of conflict in Ulster caused the emergence of an ethnic group identity that was defined as being "war-related," and was oriented toward confrontation with the "enemy" and defense of the group's rights. The author analyzes examples of creating common actions, initiated both from below 
and from the top down (the "shared future" policy), paying attention to the potential changes in ethnic attitudes and identities, in order to verify her assumptions.

Key words / słowa kluczowe

Northern Ireland / Irlandia Północna, war-related ethnic identity / „wojenna” tożsamość etniczna, peace process / proces pokojowy, social change / zmiana społeczna 